\title{
THE INVESTIGATION OF THE RELATIONSHIP BETWEEN SUSTAINABLE SUPPLY CHAIN MANAGEMENT AND SUSTAINABLE COMPETITIVE ADVANTAGE ACCORDING TO THE MEDIATING ROLE OF INNOVATION AND SUSTAINABLE PROCESS MANAGEMENT
}

Sajad Vafaei

sajadvafaei021@gmail.com Department of Public

Management, North Tehran Branch, Islamic Azad University, Tehran, Iran.

\section{Ardeshir Bazrkar}

Ardeshir.Bazrkar@gmail.com Department of Industrial Management, North Tehran Branch, Islamic Azad University, Tehran, Iran.

Mohammad Hajimohammadi mohammad.hmohammadi64@ gmail.com

Department of Public Management, North Tehran Branch, Islamic Azad University, Tehran, Iran.

\begin{abstract}
Goal: The present study examines the mediating role of innovation and sustainable process management on the relationship between sustainable supply chain management and sustainable competitive advantage.

Design / Methodology / Approach: The statistical population consists of 20 companies involved in the production of banking equipment. Since the size of the statistical population is very small, structural equations model and partial least squares approach were used to analyze the research data and to test the hypotheses of the research.

Results: The results showed that there is a positive and significant relationship between sustainable supply chain management and sustainable competitive advantage. Moreover, it was found that innovation and sustainable process management variables play a mediating and moderating role on the relationship between sustainable supply chain and sustainable competitive advantage.

Limitations of the investigation: The most important limitation in this study was the longtime collection of research data.

Practical implications: According to the results obtained, organizations should focus on applying the principles of sustainable process management to achieve coordination between the departments and resources of the organization.

Originality / Value: It is recommended that organizations emphasize innovative and creative activities to achieve sustainable competitive advantage through sustainable supply chain activities.
\end{abstract}

Keywords: Sustainable Supply Chain Management, Sustainable Competitive Advantage, Innovation, Sustainable Process Management, Structural Equation model. 


\section{INTRODUCTION}

The study of the evolution of management shows that companies have focused on supply chain management in order to cope with increasing environmental changes and to improve organizational performance and obtain more market share and competitive advantage. Studies have revealed that effective supply chain management (Fritz et al., 2017) increases performance, customer satisfaction, and competitive advantage, and reduces pessimism due to its positive impact on human resources.

Today, cost advantage is largely achieved through supply chain management (Govindan et al., 2014). Sustainable supply chain management addresses the economic, social, and environmental needs of suppliers and customers. The SSCM structure is considered as a prerequisite for sustainable success. Designing a sustainable supply chain management structure provides a competitive advantage for companies (Büyüközkan, 2011). The implementation of sustainable supply chain management has been recognized as a vital factor in business sustainability (Ahi et al., 2016).

One of the factors that has influenced sustainable supply chain management activities and has been investigated in a variety of research is innovation. A number of researchers have pointed out that innovative companies have better performance regarding sustainability (Pagell and Wu, 2009; Nidumolu et al., 2009). Today, achieving goals, such as enhancing productivity and increasing profits, obtaining new markets and improving market share, happens through innovative activities (Deniz, 2015). On the one hand, with the expansion of communications and the reduction of the impact of geographical boundaries, organizations are increasingly in a competitive environment, so that the importance of building and maintaining sustainable competitive advantage is increasing.

Sustainable competitive advantage couldn't be copied and used by others and could help the organization to compete in a sustainable manner (Coyne, 1986). On the other hand, with the emergence of discussions regarding Sustainable Development, new issues have emerged concerning supply chain, although different definitions and dimensions for the sustainable supply chain have been described (Ahi et al., 2016).

Sustainable supply chain management can be defined as: Managing the flow of materials and information and coordinating them throughout the supply chain, simultaneously taking into account the economic, social and environmental dimensions. Although there is no comprehensive consensus about the definition of sustainable supply chain management, it is supported as a new model because the compa- ny's activity, while meeting the needs of the stakeholders and increasing profitability and competitiveness, requires increasing environmental efficiency and social accountability of the supply chain (Zhu et al., 2013). The key question that this research seeks to answer is whether innovation and sustainable process management mediate the relationship between sustainable supply chain management and sustainable competitive advantage.

In previous studies, the role of innovation, in relation to sustainable supply chain and sustainable competitive advantage, has been separately studied. In the present study, in addition to investigating the role of innovation on the relationship between sustainable supply chain and sustainable competitive advantage, the role of sustainable process management will also be investigated. The conceptual model of this research was designed based on theoretical fundamentals and the research background and to enhance the sustainable competitive advantage through sustainable supply chain management, innovation and sustainable process management, as shown in Figure 1.

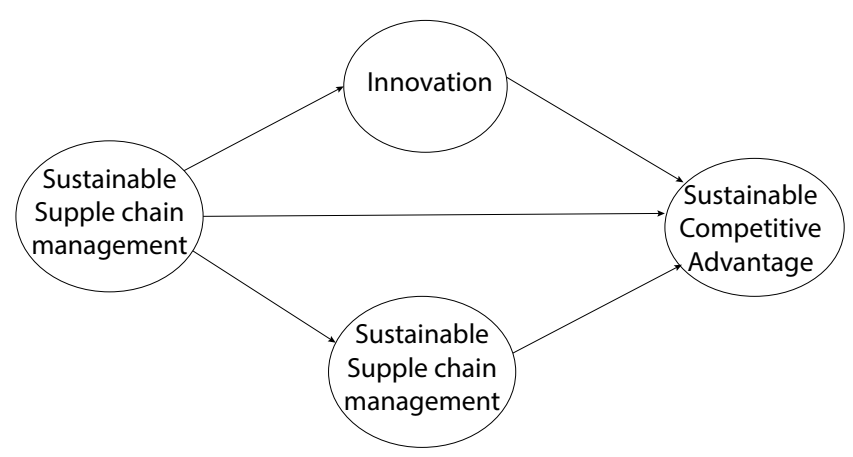

Figure 1. Conceptual model of research Research hypotheses

According to the research purpose, variables and the conceptual model of the research, the hypotheses of this research are demonstrated as follows:

H1: There is a positive and significant relationship between sustainable supply chain management and competitive advantage.

$\mathrm{H} 2$ : There is a positive and significant relationship between sustainable supply chain management and innovation.

H3: There is a positive and significant relationship between sustainable supply chain management and sustainable process management.

H4: There is a positive and significant relationship between innovation and sustainable competitive advantage. 
H5: There is a positive and significant relationship between sustainable process management and sustainable competitive advantage.

H6: There is a positive and significant relationship between sustainable supply chain management and sustainable competitive advantage with respect to the mediating role of innovation.

H7: There is a positive and significant relationship between sustainable supply chain management and sustainable competitive advantage with respect to the mediating role of sustainable process management.

\section{LITERATURE REVIEW}

\section{Sustainable Supply Chain Management}

Considering sustainable supply chain management, supplier selection decisions and supplier-related policies are extremely important. The globalization and inter-continental outsourcing, as well as the sustainability issues, has increased the importance of sustainable supply chain management for developing organizational strategies and survival in a competitive environment (Seuring and Muller, 2008).

The supply chain concept has existed for a long time. The supply chain is a system of organizations, people, technologies, activities, information and other resources for delivering a product or service from the supplier to the customer. The supply chain is defined by five players: inputs suppliers, producers, originators, and processing industry (Rósis and Mesquita, 2018). The supply chain is also defined as a system of integrated business activities throughout a product's life-cycle that provide value to stakeholders and improve people's health (Hussain, 2011).

Sustainable supply chain management refers to the management of the flow of materials, information and capital, as well as collaboration among companies along the supply chain, as well as the integration of goals from all sustainable development strategies tailored to the needs of customers and stakeholders (Seuring and Muller, 2008).

In the literature regarding sustainable supply chain management, two distinct sustainable supply chain operations have been identified: Sustainable process management and sustainable supply management. Sustainable process management consists of basic environmental and social activities that are usually used without direct supplier involvement, such as economic design and health and safety actions (Zhu et al, 2013). Sustainable supply management includes activities that are related to transactions with suppliers such as sustainable and long-term assessment and cooperation with suppliers (Klassen and Vereecke, 2012).

\section{Sustainable competitive advantage}

Conservation and sustainability, as well as their development, require an on-time understanding of the environment opportunities and changes in the game rules. Organizations that can understand the new game rules have a better chance to benefit from the opportunities (Bazrkar and Iranzadeh, 2017).

Competitive advantage refers to the features-driven and resources-driven ability (Tseng et al., 2008). By competitive advantage, an organization defends itself against competitors and also includes features that allow the organization to distinguish itself from its competitors (Li et al., 2006). Competitive advantage is related to unique resources and competencies lacked by competitors, and leads to a performance better than that of competitors (Sadri and Lees, 2001).

Porter (1985) considers competitive advantage within the framework of competitive strategy. He considers the competitive strategy as a determinant for the company position in a competitive environment. The goal of competitive strategy is to guide the market by understanding and anticipating economic factors, especially the behavior of other competitors. Competitive strategy enables the company to produce a product that cannot be produced by competitors. Obviously, it is not possible to gain competitive advantage accidentally and organizations can only achieve it by thinking and planning.

According to Porter, competitive advantage lies in the center of the company's competitive performance. He argued that the competitive advantage is a company's value proposition for its customers, in such a way that the values created are higher than the customer costs (Inauen et al., 2011). Competitive advantage is one of the factors that companies use to obtain a better position in the market compared to their competitors and is obtained when the buyer has a more perceptive value for a product than for other products. Sustainable competitive advantage is obtained when other competitors cannot easily or quickly mimic this value (Li and Toppinen, 2011). A sustainable competitive advantage can be broadly defined as the quality of an organization by which an organization can surpass its competitors and increase its returns.

\section{Innovation}

Innovation can be a valuable tool for social and environmental issues during corporate operations. The innovative 
companies have accustomed themselves to developing efficient and effective systems to predict opportunities and use these systems to upgrade themselves and overcome organizational deficiencies (Gualandris and Kalchschmidt, 2014). As the pressure of global competition increases, companies are constantly forced to develop and innovate in order to increase the competitiveness of products and services in areas, such as product design, technology, and reliability.

The integrative approach suggests that value creation for service organizations may be embedded in an innovation value chain, consisting of generating ideas, converting them into products and disseminating practices and products obtained by the organization (Jacintho et al., 2018). A company should expand its innovative capabilities for the development and commercialization of new technologies, facilitate the creation and distribution of technological innovations throughout the organization, and strengthen its competitive advantage (Cheng et al., 2012). Innovation can be a new method for the production of products and services or new and up to date processes (Filipescu et al., 2013).

Porter (1985) states that ignoring and having a static mind prevents companies from realizing that their environmental and social performance can be improved along with decreasing costs, which limits the development of sustainable supply chain management activities. Instead, creative thinking and innovation are key factors to deal with the challenges of sustainability. The ability of a company to innovate is greatly related to the rapid development of a new product, the adoption of the latest technological innovations within processes, the number of innovations, and being the first for the marketing of the new product (Prajogo and Sohal, 2003). These characteristics are fundamental to the survival and sustainability of an organization.

\section{RESEARCH METHODOLOGY}

The present study is an applied research in terms of purpose and a descriptive - survey research related to the data collection method. The statistical population of this research $(n=20)$ consists of companies manufacturing banking equipment in Iran, because only 20 companies are active in this field. Twenty questionnaires were distributed among these companies' managers. After one month, 20 completed questionnaires were collected (return rate $=100 \%$ ). The data were collected using a questionnaire that consists of seven items measuring the sustainable supply chain management (Gualandris and Kalchschmidt, 2014), and sixteen items measuring sustainable competitive advantage ( $\mathrm{Li}$ et al., 2006; Fahy, 2002), emphasizing sustainable price, sustainable quality, sustainable delivery and sustainable product innovation. In addition, the questionnaire consists of four items measuring innovation, and four items measuring sustainable process management (Gualandris and Kalchschmidt, 2014), emphasizing sustainability aspects.

The content validity and face validity were used to determine the validity of the data collection tool (questionnaire). Thus, in the first step, by studying previous research and using standard questionnaires and modifying them, the use of suitable and acceptable indicators was attempted. Then, the initial questionnaires were designed and sent to five experts for approval.

After collecting the five initial questionnaires, the Cronbach's alphas for the variables of the research were calculated. Due to the fact that the structural equation model with partial least squares approach has low sensitivity to sample size, normalization of data is not a necessary condition for the implementation of the model. Due to the small size of the statistical population in this study, this method was used for data analysis. Considering the exploratory nature of the research model, the bootstrapping command was used in the Smart PLS software in this research.

\section{DATA ANALYSIS}

The research findings were descriptively and inferentially analyzed.

\section{Descriptive data analysis}

The mean value and standard deviations of the variables of the research obtained through the analysis of the results of the collected questionnaires are presented in Table 1.

Table 1. Descriptive analysis of Main Research Variables

\begin{tabular}{|c|c|c|}
\hline Variable & mean & $\begin{array}{c}\text { Standard } \\
\text { deviation }\end{array}$ \\
\hline Sustainable Supply Chain Management & 4.91 & 0.921 \\
\hline Sustainable Competitive Advantage & 5.20 & 1.13 \\
\hline Innovation & 4.80 & 0.956 \\
\hline Sustainable Process Management & 4.73 & 0.991 \\
\hline
\end{tabular}

According to Table 1 , all mean values for the main research variables are higher than 4 , which is above average. The small amount of the standard deviation of a variable indicates the very low scattering of that variable.

\section{Inferential data analysis}

In this research, structural equation model and path analysis were used to evaluate the research hypotheses. The verification of the basic structural model consists of three parts: 
verifying the measurement models, verifying the structural model and verifying the overall model:

\section{Verifying the measurement model}

Reliability, convergent validity and divergent validity were used to examine the fitting index of measurement models. First, the factor load of the questionnaire items was examined. The criterion for the suitability of factor load is 0.4 . The results of the factor loads have been displayed in Table 2 .

Table 2. Factor load coefficients for each variable

\begin{tabular}{|c|c|c|c|}
\hline \multicolumn{2}{|c|}{ Variables } & Items & $\begin{array}{c}\text { Factor } \\
\text { load }\end{array}$ \\
\hline \multirow{7}{*}{\multicolumn{2}{|c|}{ Sustainable Supply Chain Management }} & 1 & 0.812 \\
\hline & & 2 & 0.860 \\
\hline & & 3 & 0.753 \\
\hline & & 4 & 0.829 \\
\hline & & 5 & 0.865 \\
\hline & & 6 & 0.796 \\
\hline & & 7 & 0.771 \\
\hline \multirow{16}{*}{$\begin{array}{l}\text { Sustainable competi- } \\
\text { tive advantage }\end{array}$} & \multirow{4}{*}{ Sustainable price } & 8 & 0.852 \\
\hline & & 9 & 0.713 \\
\hline & & 10 & 0.791 \\
\hline & & 11 & 0.658 \\
\hline & \multirow{5}{*}{$\begin{array}{l}\text { Sustainable } \\
\text { quality }\end{array}$} & 12 & 0.812 \\
\hline & & 13 & 0.913 \\
\hline & & 14 & 0.888 \\
\hline & & 15 & 0.754 \\
\hline & & 16 & 0.861 \\
\hline & \multirow{4}{*}{$\begin{array}{l}\text { Sustainable inno- } \\
\text { vation }\end{array}$} & 17 & 0.697 \\
\hline & & 18 & 0.754 \\
\hline & & 19 & 0.682 \\
\hline & & 20 & 0.793 \\
\hline & \multirow{3}{*}{$\begin{array}{l}\text { Sustainable de- } \\
\text { livery }\end{array}$} & 21 & 0.815 \\
\hline & & 22 & 0.695 \\
\hline & & 23 & 0.745 \\
\hline \multirow{4}{*}{\multicolumn{2}{|c|}{ Innovation }} & 24 & 0.697 \\
\hline & & 25 & 0.867 \\
\hline & & 26 & 0.889 \\
\hline & & 27 & 0.735 \\
\hline \multirow{4}{*}{\multicolumn{2}{|c|}{ Sustainable process management }} & 28 & 0.777 \\
\hline & & 29 & 0.668 \\
\hline & & 30 & 0.716 \\
\hline & & 31 & 0.829 \\
\hline
\end{tabular}

According to Table 2, all 31 factor loads (corresponding to 31 items) are higher than 0.4 , so that the goodness-of-fit for all items is acceptable.

The Cronbach's alpha, reliability coefficient (RC) and average variance extracted (AVE) are presented in Table 3. The
Cronbach's alpha is higher than 0.7 indicating acceptable reliability. In the PLS method, a newer criterion compared to Cronbach's Alpha has been introduced: composite reliability. Its superiority to Cronbach's alpha is that the reliability of the constructs is calculated in terms of the correlation among constructs rather than as an absolute value. The AVE represents the average amount of variance. Fornell and David (1981) introduced the AVE for calculating convergent validity, and stated that its critical value is 0.5 . This means that, for the AVE values greater than 0.5 , convergent validity is acceptable.

Table 3. Cronbach's alpha, composite reliability and convergent validity

\begin{tabular}{|c|c|c|c|c|}
\hline Variable & $\begin{array}{c}\text { Cronbach's } \\
\text { alpha co- } \\
\text { efficients } \\
\text { (Alpha> } \\
\mathbf{0 . 7 )}\end{array}$ & $\begin{array}{c}\text { com- } \\
\text { posite } \\
\text { reliability } \\
\text { (CR> 0.7) }\end{array}$ & $\begin{array}{c}\text { Average } \\
\text { variance } \\
\text { extract- } \\
\text { ed } \\
\text { AVE> 0.5 }\end{array}$ & $\begin{array}{c}\text { Com- } \\
\text { munal- } \\
\text { ity> 0 }\end{array}$ \\
\hline $\begin{array}{c}\text { supply chain } \\
\text { management }\end{array}$ & 0.87 & 0.92 & 0.61 & 0.49 \\
\hline sustainable price & 0.84 & 0.88 & 0.66 & 0.58 \\
\hline $\begin{array}{c}\text { sustainable } \\
\text { quality }\end{array}$ & 0.89 & 0.95 & 0.68 & 0.53 \\
\hline $\begin{array}{c}\text { sustainable } \\
\text { innovation }\end{array}$ & 0.79 & 0.83 & 0.65 & 0.79 \\
\hline $\begin{array}{c}\text { sustainable } \\
\text { delivery }\end{array}$ & 0.80 & 0.86 & 0.71 & 0.51 \\
\hline $\begin{array}{c}\text { sustainable } \\
\text { competitive } \\
\text { advantage }\end{array}$ & 0.88 & 0.91 & 0.60 & 0.46 \\
\hline Innovation & 0.81 & 0.89 & 0.69 & 0.48 \\
\hline $\begin{array}{c}\text { sustainable pro- } \\
\text { cess manage- } \\
\text { ment }\end{array}$ & 0.78 & 0.84 & 0.65 & 0.66 \\
\hline
\end{tabular}

According to table 3 , the reliability and convergent validity of the conceptual model of the research are confirmed. Meanwhile, to investigate the divergent validity of the research model, the correlation of a construct will be compared with its indicators against the correlation of this construct with other constructs. The results are exhibited in table 4.

According to Table 4, the constructs have more correlations with their indicators and the divergent validity of the research model is acceptable.

\section{Investigating the structural model of the research}

Contrary to measurement models, the structural model deals with hidden variables and in this study, the correlations among them are examined. In the present study, for evaluating the structural model, the significance levels t-Val- 
Table 4. Divergent validity

\begin{tabular}{|c|c|c|c|c|c|c|c|}
\hline & SCM & SP & SQ & SI & SD & INN & SPM \\
\hline SCM & 0.692 & & & & & & \\
\hline SP & 0.605 & 0.751 & & & & & \\
\hline SQ & 0.599 & 0.523 & 0.710 & & & & \\
\hline SI & 0.613 & 0.548 & 0.464 & 0.845 & & & \\
\hline SD & 0.599 & 0.499 & 0.524 & 0.630 & 0.677 & & \\
\hline INN & 0.563 & 0.434 & 0.550 & 0.633 & 0.482 & 0.639 & \\
\hline SPM & 0.631 & 0.603 & 0.622 & 0.598 & 0.611 & 0.552 & 0.812 \\
\hline
\end{tabular}

ue, $R^{2}$ and $Q^{2}$ are examined. If t-value exceeds 1.96 , the relationship between the constructs is significant and research hypotheses are confirmed at $95 \%$ confidence level. Considering the t-values (Fig. 2), it is concluded that this value is greater than 1.96 and is significant at $95 \%$ confidence level for all items and relationships among the research variables.

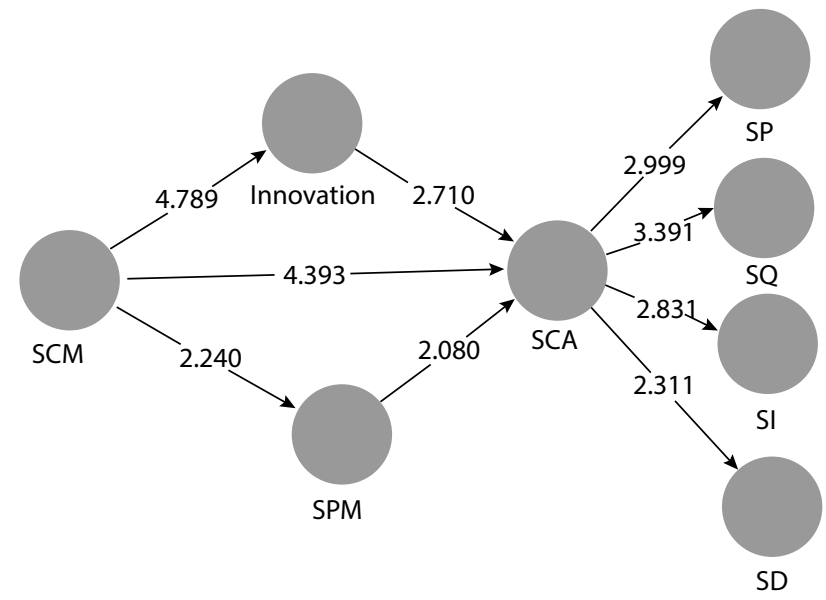

Figure 2. Standardized factor loads of the structural model of research

The second criterion for evaluating the research structural model is $R^{2}$ coefficients, associated with endogenous hidden variables, which represent the impact of an exogenous variable on an endogenous variable. The higher the $\mathrm{R}^{2}$ values related to the endogenous (dependent) constructs of a model, the better the model fit (Henseler, 2009). In most studies, $0.19,0.33$ and 0.67 values are considered as a criterion for weak, moderate and strong $\mathrm{R}^{2}$, respectively. The results of this study showed that the $R^{2}$ values for endogenous variables are: innovation $=0.489$, sustainable process management $=0.587$, sustainable competitive advantage $=$ 0.699 , sustainable price $=0.842$, sustainable quality $=0.935$, sustainable innovation $=0.666$ and sustainable delivery $=$ 0.734 . According to the $R^{2}$ values, the structural model fitness is confirmed and there is a moderate to strong correlation between the constructs.

The third criterion is $Q^{2}$ (introduced by Stone-Geisser in 1975). This criterion identifies the predictive power of model, and models that have acceptable structural model fitness should be able to predict the related endogenous constructs. Henseler (2009), considered 0.02.0.15 and 0.35 values as a criterion for weak, moderate and strong predictive power related to endogenous constructs, respectively. If the $Q^{2}$ values were zero or less than zero, the model would need to be corrected (Table 5).

Table 5. $Q^{2}$ coefficients for research variables

\begin{tabular}{|c|c|}
\hline Constructs & Q2 \\
\hline Innovation & 0.421 \\
\hline Sustainable process management & 0.276 \\
\hline Sustainable competitive advantage & 0.332 \\
\hline Sustainable price & 0.623 \\
\hline Sustainable quality & 0441 \\
\hline Sustainable innovation & 0.265 \\
\hline Sustainable delivery & 0.352 \\
\hline
\end{tabular}

According to Table 5, it can be concluded that the structural model fitness is desirable and the variables have moderate to strong predictive power.

\section{The overall model fit}

To examine the overall model fit that controls both the measurement and structural models, the GOF (goodness of fit) is calculated as follows:

\section{$\mathrm{GOF}=$ Vaverage (Communality)* average $\mathrm{R}^{2}$}

The GOF was developed by Tenenhaus et al (2004), and Wetzells et al (2009) introduced $0.01,0.25$ and 0.36 values as a criterion for weak, moderate and strong GOF, respectively.

According to the GOF, the communality and $R^{2}$ values (Table 3) for the research variables are 0.562 and 0.707 , respectively.

\section{GOF $=$ Vaverage (Communality)* average $\mathrm{R}^{2}=0.397$}

The result shows a strong GOF for the overall research model. 
Brazilian Journal of Operations \& Production Management

Volume 16, Número 4, 2019, pp. 572-580

DOI: 10.14488/BJOPM.2019.v16.n4.a3

\section{Hypotheses Test}

According to the algorithm of data analysis via the PLS method, after examining the fitness of the measurement, structural and total models, the research hypotheses are tested by examining $Z$ as well as the standardized factor loads related to the paths. If the significance coefficients of each path were more than 1.96, then the path is significant at $95 \%$ confidence level and the related hypothesis is confirmed. The test results of the research hypothesis have been presented in Table 6.

Table 6: Test results of the main research hypotheses

\begin{tabular}{|c|c|c|c|}
\hline Hypothesis & $\begin{array}{c}\text { path } \\
\text { coefficient }\end{array}$ & t - value & result \\
\hline $\begin{array}{c}\text { H1 : sustainable supply } \\
\text { chain management and } \\
\text { sustainable competitive } \\
\text { advantage }\end{array}$ & 0.451 & 4.393 & confirmed \\
\hline $\begin{array}{c}\text { H2: sustainable supply } \\
\text { chain management and } \\
\text { innovation }\end{array}$ & 0.328 & 4.789 & confirmed \\
\hline $\begin{array}{c}\text { H3: sustainable supply } \\
\text { chain management and } \\
\text { sustainable process man- } \\
\text { agement }\end{array}$ & 0.835 & 2.240 & confirmed \\
\hline $\begin{array}{c}\text { H4 : innovation and } \\
\text { sustainable competitive } \\
\text { advantage }\end{array}$ & 0.471 & 2.710 & confirmed \\
\hline $\begin{array}{c}\text { H5 : sustainable pro- } \\
\text { cess management and } \\
\text { sustainable competitive } \\
\text { advantage }\end{array}$ & 0.258 & 2.080 & confirmed \\
\hline $\begin{array}{c}\text { H6: sustainable supply } \\
\text { chain management and } \\
\text { sustainable competitive } \\
\text { advantage, given the medi- } \\
\text { ating role of innovation }\end{array}$ & 0.445 & 12.978 & confirmed \\
\hline $\begin{array}{c}\text { H7 : sustainable supply } \\
\text { chain management and } \\
\text { sustainable competitive } \\
\text { advantage, given the me- } \\
\text { diating role of sustainable } \\
\text { process management }\end{array}$ & 0.755 & 4.659 & confirmed \\
\hline
\end{tabular}

According to Table 6, all t-values are higher than 1.96 for research hypotheses. Hence, all the research hypotheses are confirmed.

\section{DISCUSSION AND CONCLUSION}

The purpose of this study was to investigate the relationship between the sustainable supply chain management and the sustainable competitive advantage in terms of the mediating role of innovation and sustainable process man- agement among manufacturers of banking equipment. The results of the structural equation modeling confirmed all the research hypotheses.

In the first hypothesis of this study, the relationship between sustainable supply chain management and sustainable competitive advantage were investigated. The hypothesis test showed a t-value of 4.393 and, since this value is above 1.96, there is a positive and significant relationship between sustainable supply chain management and sustainable competitive advantage. This result was consistent with the results of Klassen and Vereecke (2012), Ahi and Searcy (2013), Li et al. (2006), Li and Toppinen (2011) studies. Therefore, it's clear that sustainable supply chain management activities provide a sustainable competitive advantage for the organization.

The second hypothesis test showed that there is a positive and significant relationship between sustainable supply chain management and innovation. This result was consistent with the results of Handfield (1998). Gualandris and Kalchschmidt (2014) studies. Hence, during sustainable supply chain management activities, which are implemented by an organization in relation to its suppliers, the innovation can be effective in finding ways to communicate with suppliers and to coordinate relations consistent with them.

The third hypothesis test revealed that there is a positive and significant relationship between the sustainable supply chain management and sustainable process management. This result was consistent with the study results of Gavronski et al. (2011), Gualandri and Kalchschmidt (2014), and Klassen and Vachon (2003). This means that the internal activities that an organization implements to improve its environmental and social performance is influenced by its external activities in relation to suppliers.

The fourth hypothesis test research revealed that there is a positive and significant relationship between innovation and sustainable competitive advantage. The result was consistent with the study results of Cagliano et al. (2016), Chong et al. (2011), and Gualandri and Kalchschmidt (2014). Therefore, innovation capabilities help organizations create and develop internal activities, such as supply chain management, to achieve sustainable competitive advantage.

The fifth hypothesis test revealed that there is a positive and significant relationship between the sustainable process management and the sustainable competitive advantage. The result was consistent with the study results of Gualandri and Kalchschmidt (2014). Therefore, a timely feedback review received from the organization's products and services and the assessment of the status of competitors in the market can be helpful to better implement the processes of sustainable process management. 
The sixth hypothesis test revealed that, innovation plays a mediating role on the relationship between the sustainable supply chain management and sustainable competitive advantage. Therefore, it is recommended that organizations emphasize innovative and creative activities to achieve sustainable competitive advantage through sustainable supply chain activities.

The seventh hypothesis test revealed that the sustainable process management plays a mediating role on the relationship between sustainable supply chain management and sustainable competitive advantage. Hence, it is recommended that organizations plan organization's activities based on the sustainable process management approach to achieve sustainable competitive advantage through sustainable supply chain management. In this way, there is a good coordination between the activities of the various parts of the organization and the existing resources, and it will facilitate the achievement of a sustainable competitive advantage in organizational processes.

\section{REFERENCES}

Ahi, P. Mohamad Y. Jaber, Searcy, C. (2016), “A comprehensive multidimensional framework for assessing the performance of sustainable supply chains", Applied Mathematical Modelling, Vol. 40, No. 23-24, pp. 10153-10166.

Ahi, P., and Searcy, C. (2013), "A comparative literature analysis of definitions for green and sustainable supply chain management", Cleaner Production, Vol. 52, pp. 329-341.

Bazrkar, A., Iranzadeh, S. (2017), “Choosing a strategic process in order to apply in Lean Six Sigma methodology for improving its performance using integrative approaches of BSC and DEA", Journal of Business and Retail Management Research, Vol. 11, No. 4, pp. 114-123.

Büyüközkan, G. (2011), “Designing a sustainable supply chain using an integrated analytic network process and goal programming approach in quality function deployment", Expert Systems with Applications, Vol. 38, pp. 13731-13748.

Cagliano, R., Worley, C. G., \& Caniato, F. F. (2016), "The Challenge of Sustainable Innovation in Agri-Food Supply Chains", In Organizing Supply Chain Processes for Sustainable Innovation in the Agri-Food Industry, pp. 1-30, Emerald Group Publishing Limited.

Cheng, C. C., and Krumwiede, D. (2012), "The role of service innovation in the market orientation-new service performance linkage", Technovation, Vol. 32, No. 7, pp. 487-497.

Chong, A.Y.L., Chan, F.T.S., Ooi, K.B. et al. (2011), “Can Malaysian firms improve organizational / innovation performance via SCM?", Industrial Management \& Data Systems, Vol. 111, No. 3, pp. 410-431.
Coyne, K. P. (1986), "Sustainable Competitive Advantage: What it Is, What It isn't", Business Horizons, Vol. 29, pp. 54-61.

Deniz D. D. (2015), "Innovation Management in Global Competition and Competitive Advantage", Social and Behavioral Sciences, Vol. 195, pp. 1365-1370.

Fahy, J. (2002), "A resource-based analysis of sustainable competitive advantage in a global environment", International Business Review, Vol. 11, pp. 57-78.

Filipescu, D., Szenker, E., \& Almouzni, G. (2013), “Developmental roles of histone H3 variants and their chaperones", Trends in Genetics, Vol. 29, No. 11, pp. 630-640.

Fornell, C L, \& David F. (1981), “Evaluating Structural Equation Models with Unobservable Variables and Measurement Error", Journal of Marketing Research, Vol. 18, pp. 39-50.

Fritz, M., Schöggl, J., Baumgartner, R. (2017), "Selected sustainability aspects for supply chain data exchange: Towards a supply chain-wide sustainability assessment", Journal of Cleaner Production, Vol. 141, pp. 587-607.

Gavronski, I., Klassen, R.D., Vachon, S. et al. (2011), “Are source-based view of green supply management", Transportation Research Part E Logistics and Transportation Review, Vol. 47, pp. 872-885.

Govindan, K., Mathiyazhagan K., Devika K. et al. (2014), "Barriers analysis for green supply chain management implementation in Indian industries using analytic hierarchy process", International Journal of Production Economics, Vol. 147, Part B, pp. 555-568.

Gualandris, J., Kalchschmidt, (2014), “Customer pressure and innovativeness: Their role in sustainable supply chain management", Journal of Purchasing \& Supply Management, Vol. 20, No. 2, pp.92-103.

Handfield, R.B., Keah Choon Tan, Vijay R Kannan (1998) Supply chain management: supplier performance and firm performance Journal of Supply Chain Management, Vol. 34, p. 278.

Henseler, J. (2009), "Inter-firm network capability: how it affects buyer-supplier performance", British Food Journal, Vol. 111, No. 8, pp. 794-810.

Hussain, M. (2011), Modeling the Enablers and Alternatives for Sustainable Supply Chain Management, Concordia University, A Thesis for the Degree Master of Applied Science (Quality Systems Engineering). The Department of Concordia Institute for In.

Inauen, M., Schenker-Wicki, A. (2011), "The impact of outside-in open innovation on innovation performance", European Journal of Innovation Management, Vol. 14, No. 4, pp. 496-520.'

Jacintho, J. C., Silva, M. T., and Luzo, M. C. M. (2018), “The innovation process in hospital services: a case study in an 
occupational therapy", Brazilian Journal of Operations \& Production Management, Vol. 15, No. 2, pp. 322-329.

Klassen, R. D., Vereecke, A., (2012), "Social is use in supply chains: capabilities link responsibility, risk(opportunity), and performance", International Journal of Production Economics, Vol. 140, pp. 103-115.

Klassen, R. D., Vlachos, S. (2003), "Collaboration and evaluation in the supply chain: the impact on plant-level environmental investment", Production \& Operations Management, Vol. 12, pp. 336-352.

Li, N. and Toppinen, A. (2011), "Corporate responsibility and sustainable competitive advantage in forest-based industry: Complementary or conflicting goals?", Forest Policy and Economics, Vol. 13, pp. 113-123.

Li, S., Ragu-Nathan, B., Ragu-Nathan, T. S. et al. (2006), "The impact of supply chain management practices on competitive advantage and organizational performance", Omega, Vol. 34, pp. 107-124.

Nidumolu, R., Prahalad, C. K., Rangaswami, M. (2009), "Why sustainability is now the key driver of innovation", Harvard Business Review, Vol. 87, pp.56-64.

Pagell, M., Wu, Z. (2009), "Building a more complete theory of sustainable supply chain management using case studies of 10 exemplars", Journal of Supply Chain Manage, Vol. 45, pp. 37-56.

Porter, M (1985). Competitive advantage: creating and sustaining superior performance. New York: The Free Press.

Prajogo, D. I., and Sohal, A. S. (2003), "The relationship between TQM practices, quality performance, and innovation performance: An empirical examination", International Jour- nal of Quality \& Reliability Management, Vol. 20, No. 8, pp. 901-918.

Rosis, C. H. V., and Mesquita, M. A. (2018), "Application of Agent Based Simulation to analyze the impact of tax policy on soybean supply chain", Brazilian Journal of Operations \& Production Management, Vol. 15, No. 2, pp. 193-208.

Sadri, G. and Lees, B. (2001), "Developing Corporate Culture as a Competitive Advantage", Journal of Management Development, Vol. 20, pp. 853-859.

Seuring, S., and Muller, M. (2008), "From a literature review to a conceptual framework for sustainable supply chain management", Journal of Cleaner Production, Vol. 16, No. 15, pp. 1699-1710.

Tenenhaus, M., Amato, S. and Vinzi, V. E. (2004), "A Global Goodness-of-Fit Index for PLS Structural Equation Modelling", Proceedings of the XLII SIS Scientific Meeting, Vol. 1, pp. 739742.

Tseng, M.L., Lin, Y.H., Chiu, A.S.F. et al. (2008), “Using FANP approach on selection of competitive priorities based on cleaner production implementation: a case study in PCB manufacturer", Taiwan. Clean Technology and Environmental Policy, Vol. 10, No. 1, pp. 17-29.

Wetzels,M., Odekeken-Schroder,G.Van Oppen,C. (2009),"Using PLS path modeling for accessing hierarchical construct model:Gudlinees and empirical illustration",MIS Quarterly,Vol. 33,No.1,177.

Zhu, Q., Sarkis, J., Lai, K.H.(2013),"Institutional-based antecedents and performance outcomes of internal and external green supply chain management practices", Journal of Purchasing and Supply Management,Vo.19,No.2,106-117.

Received: 29 Dec 2018

Approved: 04 Feb 2019

DOI: 10.14488/BJOPM.2019.v16.n4.a3

How to cite: Vafaei, S.; Bazrkar, A.; Hajimohammadi, M. (2019), "The investigation of the relationship between sustainable supply chain management and sustainable competitive advantage according to the mediating role of innovation and sustainable process management", Brazilian Journal of Operations \& Production Management, Vol. 16, No. 4, pp. 572-580, available from: https://bjopm.emnuvens.com.br/bjopm/article/view/713 (access year month day). 